\title{
Anticancer Activity of Graphene Oxide/5-FU on CT26 dsRED Adenocarcinoma Cell Line
}

\section{BEHROOZ AFARIDEH ${ }^{1,4}$, MASOUMEH RAJABIBAZL $^{1,2}$, MEISAM OMIDI ${ }^{3}$, BAHRAM YAGHMAEE$^{1}$, AZAM RAHIMPOUR ${ }^{2}$, REZA KHODABAKHSHI ${ }^{4}$ and SAEEIDEH SARVARIAN ${ }^{4}$}

\author{
${ }^{1}$ Department of Clinical Biochemistry, Faculty of Medicine, Shahid Beheshti University of Medical \\ Sciences, Tehran, Iran. \\ ${ }^{2}$ Department of Tissue Engineering and Applied Cell Sciences, School of Advanced Technologies in \\ Medicine, Shahid Beheshti University of Medical Sciences, Tehran, Iran. \\ ${ }^{3}$ Protein Research Centre, Shahid Beheshti University, GC, Velenjak, Tehran, Iran. \\ ${ }^{4}$ Fayazbakhsh hospital, Social Security Organization of Iran, Tehran, Iran. \\ ${ }^{*}$ Corresponding author E-mail: Rajabi_m@sbmu.ac.ir
}

http://dx.doi.org/10.13005/ojc/3404038

(Received: March 13, 2018; Accepted: May 28, 2018)

\begin{abstract}
Cancer is one of the greatest health challenges in the world. Every year, many people die because of cancer. Chemotherapy is one of the treatment options in cancer disease. Fluorouracil) (5-FU) is one of the chemotherapy drugs, but it has relatively low toxic effect on tumor cells when it is used on free form, which also results in its poor efficacy. GO (graphene oxide) has a singleatomic layer and has several functional groups such as epoxide, carbonyl, carboxyl and hydroxyl which makes it a suitable carrier for drug loading. In the present study, we loaded 5-FU on GO nano-carrier to produce GO/5-FU, and characterized it by FT-IR. CT26 dsRED adenocarcinoma cell line was treated with GO/5-FU, free 5-FU, GO, and PBS (Phosphate buffer saline). The results showed significant inhibition of the CT26 dsRED cells using GO/5-FU compared to free 5-FU $(\mathrm{P}<0.05)$. Therefore, loaded 5-FU on GO $(\mathrm{GO} / 5-\mathrm{FU})$ could be a new approach for optimization of 5-FU tumor cytotoxicity.
\end{abstract}

Keywords: Graphene oxide, 5-FU, CT26 Ds-Red.

\section{INTRODUCTION}

Cancer is one of the health-threatening diseases. In 2015, about 90.5 million people were affected by cancer ${ }^{1}$. About 14.1 million new cases occur a year and it causes about 8.8 million deaths
$(15.7 \% \text { of deaths })^{2}$. Fluorouracil (5-FU), is one of the choice drugs for chemotherapy of several cancers ${ }^{3-5}$. $5-\mathrm{FU}$ acts in several ways, but principally as a thymidylate synthase (TS) inhibitor, synthesis of the thymidine, and the conversion of (dUMP) to (dTMP) which inhibits. Administration of 5-FU stops cancer 
cell dividing and causes cancer cell death ${ }^{6-8}$. Loading of cancer drugs on nano-carriers is one of the ways to increase their therapeutic effect and biocompatibility. Graphene oxide is hydrophilic and monomolecular layer of graphite with various of functional groups such as epoxide, carbonyl, carboxyl and hydroxyl ${ }^{9-13}$. The unique structural properties of GO has caused its wide application by many researchers as a nano-carrier to loading of several drugs. In prior studies 5-FU loaded on several nano-carriers, co-poly (d,I-lactic/glycolic acid) (PLGA) by Ywu-Jang Fu et al., ${ }^{14}$, poly (HEMA) nanoparticles by Chouhan et al., ${ }^{15}$, Pectin nanocarrier by Kumar Dutta et al., ${ }^{16}$, polyamidoamine (PAMAM) by Ly, Uyen et al., ${ }^{17}$, and poly( $\varepsilon$-caprolactone) nanoparticles (PCL NPs) by Ortiz et al., ${ }^{18}$. Although previous studies had relative success to improve the antitumor activity of 5 -FU by loading it on several nano-carriers, but more studies are need to improve the efficacy of 5 -FU through loading it on new nano-carriers. The purpose of present study was the loading of 5-FU on GO to improve its antitumor activity. We loaded 5-FU on GO nano-carrier. New compound (GO/5-FU), free 5-FU, GO and PBS treated with CT26 Ds-Red adenocarcinoma cells and the results of $\mathrm{GO} / 5-\mathrm{FU}$ group compared with the results of $5-\mathrm{FU}, \mathrm{GO}$ and PBS treated groups.

\section{MATERIALS AND METHODS}

\section{Materials}

5-FU was provided from Ebewe Pharma Co. The CT26 dsRED colon adenocarcinoma cell line purchased from Pasture Institute of Iran, then they were cultured in RPMI 1640 medium supplemented with L-glutamine (Biowest), 10\% fetal bovine serum and penicillin-streptomycin $(100 \mathrm{U} / \mathrm{ml}$ and 100 $\mathrm{mg} / \mathrm{ml}$, respectively) at $37^{\circ} \mathrm{C}$ in a $5 \% \mathrm{CO}_{2}$ humidified atmosphere. Graphite powder was purchased from Merck \& Co. Other materials provided from local suppliers.

\section{METHODS}

\section{Synthesis of graphene oxide}

Graphene oxide (GO) was synthesized by Hammer modified method ${ }^{19}$. Briefly, graphite powder ( $3 \mathrm{~g}$ ) was oxidized in $12 \mathrm{ml}$ of $\mathrm{H}_{2} \mathrm{SO}_{4}$ at the presence of $2.5 \mathrm{~g}$ of $\mathrm{K}_{2} \mathrm{~S}_{2} \mathrm{O}_{8}$ and $2.5 \mathrm{~g}$ of $\mathrm{P}_{2} \mathrm{O}_{5}$ at $80^{\circ} \mathrm{C}$ for 4.5 hours. Then the graphite oxide was neutralized using $120 \mathrm{ml}$ of precooled sulfuric acid. $\mathrm{KMnO}_{4}(15 \mathrm{~g})$ progressively added into the solution under vigorous stirring under $20^{\circ} \mathrm{C}$. Temperature was raised to $40^{\circ} \mathrm{C}$ and continued stirring for $2 \mathrm{~h}$, two times deionized water $250 \mathrm{ml}, 700 \mathrm{ml}$ and $20 \mathrm{ml}$ of $\mathrm{H}_{2} \mathrm{O}_{2}$ was added under strong stirring, respectively. For elimination of excess materials, the mixture was washed and neutralized with $100 \mathrm{ml}$ of $\mathrm{HCl}(37 \%), \mathrm{HCl}$ aqueous solution $100 \mathrm{ml}(1: 10 \mathrm{v} / \mathrm{v})$, and deionized water $(1000 \mathrm{ml})$, respectively. Neutralized graphene oxide was dried at the ambient temperature, dispersed $(0.5 \% \mathrm{wt})$ in deionized water, and dialyzed with dialysis bag (7000 Da) for one week.

\section{5-FU loading and its characterization}

5-FU $(3000 \mu \mathrm{g} / \mathrm{ml})$ was added to $\mathrm{GO}$ suspension ( $1 \mathrm{mg} \mathrm{GO} / 1 \mathrm{ml}$ of $100 \mathrm{mM} P B S$ ) and incubated on darkness condition at $37^{\circ} \mathrm{C}$ for $24 \mathrm{~h}$ while slightly shaking $(50 \mathrm{rpm})^{20}$. Unloaded 5-FU was removed by centrifugation (17740 RCF, 30 min., Eppendorf $5417 \mathrm{R}$ ) and three times washed with PBS (100 mM, pH 7.4).

\section{Cells culture and MTT assay}

CT26 Ds-Red colon adenocarcinoma cell line was cultured in RPMl1640 medium supplemented with L-glutamine (Biowest), fetal bovine serum $10 \%$ and penicillin-streptomycin $(100 \mathrm{U} / \mathrm{ml}$ and $100 \mathrm{mg} / \mathrm{ml}$, respectively) at $37^{\circ} \mathrm{C}, 5 \% \mathrm{CO}_{2}$ and humidified atmosphere. MTT assay applied to measure the cytotoxicity of (GO/5-FU), free 5-FU, GO and PBS ${ }^{21}, 22$. CT26 dsRED cells seeded and incubated overnight at $37^{\circ} \mathrm{C}, 5 \% \mathrm{CO}_{2}$ humidified atmosphere, then the cells were treated by GO/5-FU, free 5-FU, GO and PBS. For each groups we considered four well (quadruplicate). After $24 \mathrm{~h}$ incubation at $37^{\circ} \mathrm{C}, 5 \% \mathrm{CO}_{2}$ and humidified atmosphere, $20 \mu \mathrm{l}$ MTT solution was added and incubated for $4 \mathrm{~h}$ at $37^{\circ} \mathrm{C}$, then medium and MTT were removed. DMSO $(200 \mu \mathrm{l})$ was added to all wells. Incubation was done for $15 \mathrm{~min}$. in ambient temperature and darkness. Absorbance was measured by a microplate reader (Anthos 2020, $540 \mathrm{~nm}$ ). To calculate the cell viability (\%) the following formula was used ${ }^{23}$.

Cell viability $(\%)=($ mean absorbance of treated cells/ mean absorbance of control cells) $\times 100$

\section{Statistical analyses}

Data were analyzed with Graphpad Prism 6. Student's t-test was used for analysis of the results 
between two groups. Data was presented as mean \pm standard deviation (SD). Results were considered statistically significant at $\mathrm{P}<0.05$.

\section{RESULTS AND DISCUSSION}

\section{Synthesis and characterization of GO}

Graphite used for synthesis of GO according of modified Hummers' method ${ }^{10}$. Obtained GO was characterized by atomic force microscopy (AFM), transition electron microscopy (TEM), X-ray powder diffraction (XRD) and FTIR spectroscopy methods to detect the shape, size, and chemical structure of obtained GO 24 (Figure 1).

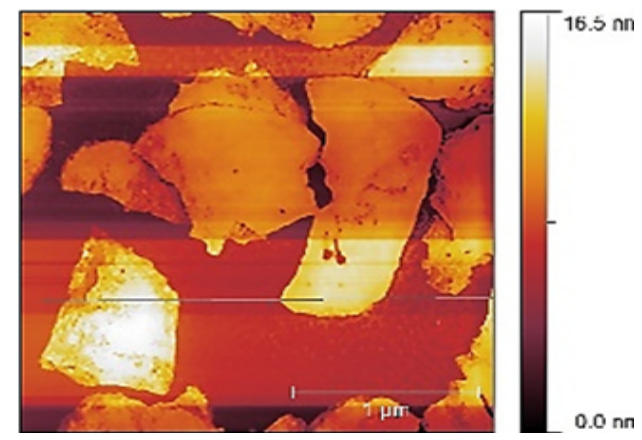

(a)

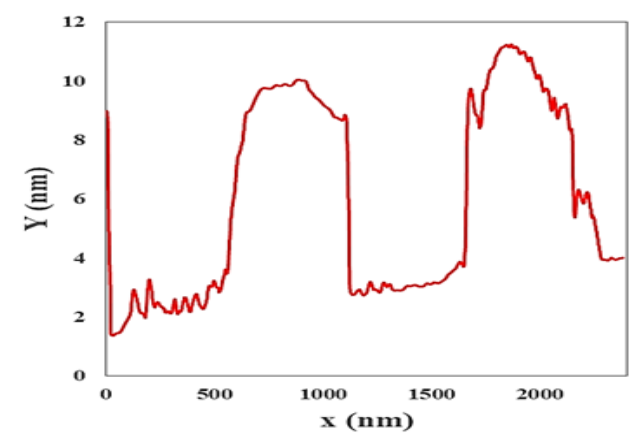

(c)

\section{Drug loading and characterization}

5-FU loaded on GO nano-carrier according as described in materials and methods. Loaded 5-FU calculated by UV-Vis spectrophotometry (CECIL CE 2041, 265 nm). 5-FU standard curve provided according to calculated absorbance for serial dilutions of 5-FU (Table 1, Fig. 2). Loaded 5-FU concentration was calculated according the following formula:

Loaded 5-FU = (initial 5-FU concentration -5 -FU concentration in supernatant)

The concentration of 5-FU on supernatant was $1254(\mu \mathrm{g} / \mathrm{ml})$ and initial concentration of 5-FU

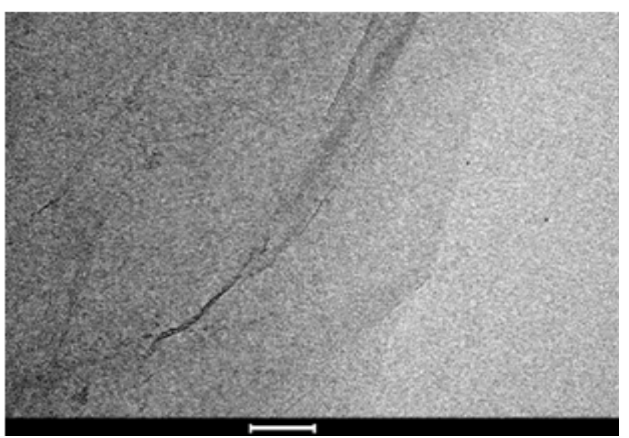

(b)

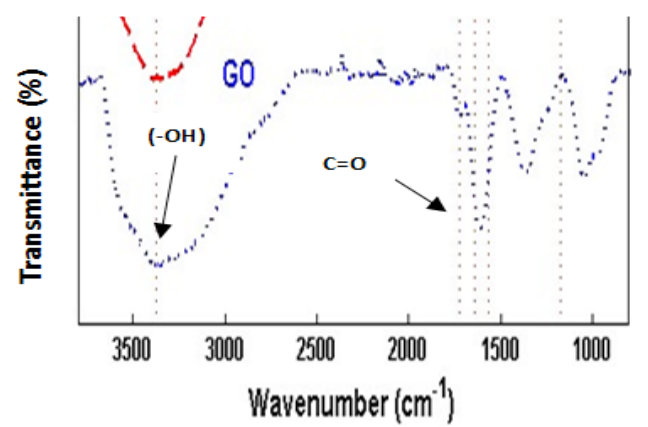

(d)

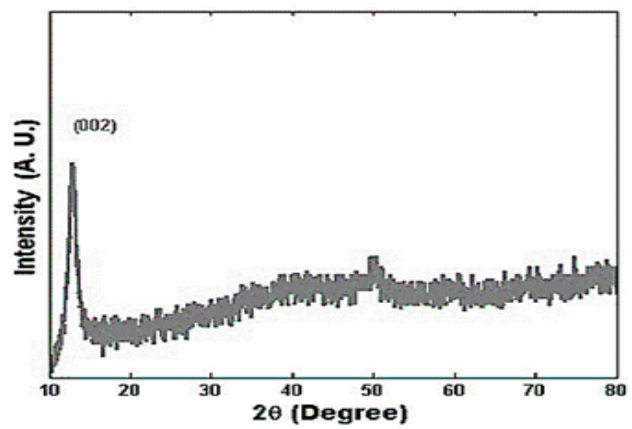

(e)

Fig. 1. (a) AFM (atomic force microscopy)image and height profile of GO, (b)TEM (transition electron microscopy) of GO, (c) FTIR of $\mathrm{GO},(-\mathrm{OH})$ and $(\mathrm{C}=\mathrm{O})$ spectrums of $\mathrm{GO}$ carboxyl group, were appeared at $\left(3374 \mathrm{~cm}^{-1}\right)$ and $\left(1710 \mathrm{~cm}^{-1}\right)$, respectively. (d) X-ray powder diffraction (XRD) patterns of GO 
was $3000(\mu \mathrm{g} / \mathrm{ml})$. Therefore, in our study the concentration of loaded 5-FU on GO nano-carrier was $1746(\mu \mathrm{g} / \mathrm{ml})$. Dilution was performed for high concentration samples.

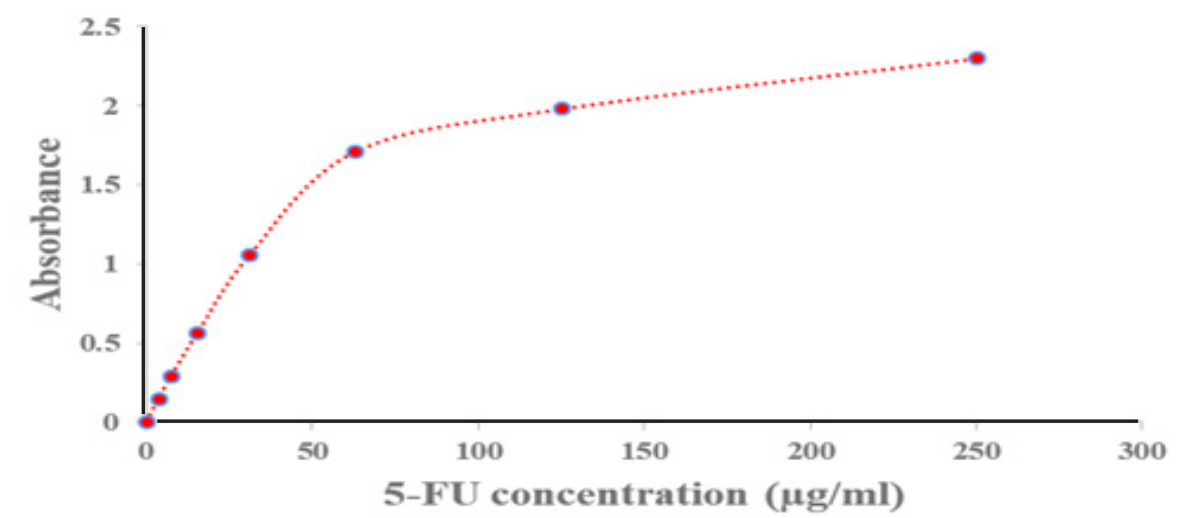

Fig. 2. 5-FU standard curve, 5-FU serial dilutions were $0,3.75,7.5,15.5,31,63,125$ and $250(\mu \mathrm{g} / \mathrm{ml})$, respectively

\begin{tabular}{cc}
$\begin{array}{c}\text { Table 1: Calculated absorbance for } \\
\text { serial dilution of 5-FU by UV-Vis } \\
\text { spectrophotometry at } \mathbf{2 6 5} \mathbf{~ n m}\end{array}$ \\
\hline $\begin{array}{c}5-F U \\
(\mu \mathrm{g} / \mathrm{ml})\end{array}$ & Concentration \\
\hline 0 & 0 \\
3.75 & 0.145 \\
7.5 & 0.29 \\
15.5 & 0.565 \\
31 & 1.052 \\
63 & 1.71 \\
125 & 1.98 \\
250 & 2.3 \\
\hline
\end{tabular}

\section{Cytotoxic activity of GO/5-FU}

MTT assay was used to detect the cytotoxicity effect of GO/5-FU. We assayed GO/5-FU, free 5-FU, GO and PBS (100mM) on CT26 dsRED adenocarcinoma cell line, the results are shown in (Fig. 3, Table 2). The inhibition of CT26 dsRED cell line by $\mathrm{GO} / 5-\mathrm{FU}$ was significantly higher compared to free $5-\mathrm{FU}(\mathrm{P}<0.017)$ (Figure 3).

\section{GO/5-FU IC}

$\mathrm{IC}_{50}{ }_{50}$ is a drug concentration which inhibit the growth of $50 \%$ cells $^{25}$. Calculated IC ${ }_{50}$ in present study for $\mathrm{GO} / 5-\mathrm{FU}$ and free 5 -FU was $5.2 \mathrm{\mu g} \mathrm{m}^{-1}$ and $8.1 \mu \mathrm{g} \mathrm{ml}^{-1}$, respectively. These results showed the $\mathrm{IC}_{50}$ of $\mathrm{GO} / 5-\mathrm{FU}$ was $35.8 \%$ lower compared to free 5 -FU. In the other words, inhibition potency of $\mathrm{GO} / 5-\mathrm{FU}$ was higher (35.8\%) in comparison with free 5-FU (Table 2).

Table 2: Calculated IC $\mathrm{C}_{50}$ for GO/5-FU, free 5-FU and GO

\begin{tabular}{|c|c|}
\hline Samples & $\mathrm{IC}_{50}\left(\mu \mathrm{g} \mathrm{ml}^{-1}\right)$ \\
\hline $\begin{array}{l}\text { GO/5-FU } \\
5-F U \\
\text { GO }\end{array}$ & $\begin{array}{c}5.2^{*} \\
8.1 \\
28.9\end{array}$ \\
\hline $\begin{array}{l}\text { The IC } \\
\text { significa } \\
\text { compare }\end{array}$ & $\begin{array}{l}\text { f } \mathrm{GO} / 5-\mathrm{FU} \\
\text { was lower in } \\
\text {-FU }\left({ }^{\star} \mathrm{P}<0.05\right)\end{array}$ \\
\hline
\end{tabular}

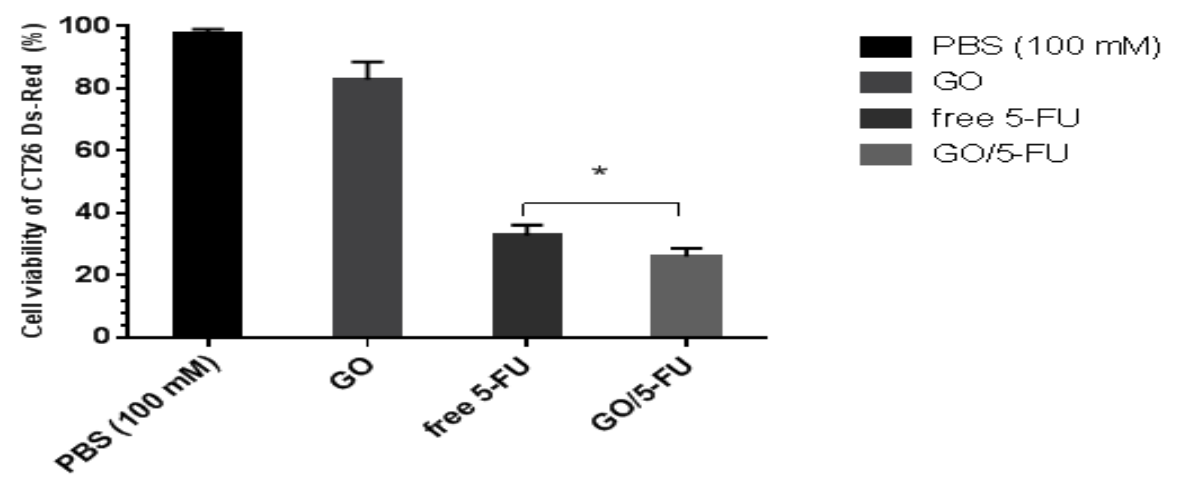

Fig. 3. Cytotoxic effect of GO/5-FU, free 5-FU, GO and PBS. MTT assay was used to assay of cytotoxic effect (see material and method). Data presented as mean \pm SD. Inhibition of CT26 dsRED cell by GO/5-FU was significant, $(\mathrm{P}<0.017)$. 
Loading of anticancer drugs on several nano-carriers is a new concept on chemotherapy and in the recent years, extensive research has been conducted on this subject. Fluorouracil (5-FU) is a common anticancer drug which is used in several cancers but its efficacy is low. The purpose of present study was improving the efficacy of 5-FU by loading it on $\mathrm{GO}$ nano-carrier. Our results showed that loaded 5-FU on GO (GO/5-FU) significantly inhibited CT26 dsRED adenocarcinoma cell line compared to its free form (5-FU). This improvement may be due to slow and steady release of 5-FU when it loaded on GO nano-carrier. The results are in agreement with those of TU et al.,17, NQ et al., ${ }^{26}$, El-Ghannam et al.. ${ }^{27}$, Ganguly et al.., ${ }^{28}$ and Liu et al.., ${ }^{29}$. However, our findings do not support those of Wang et al., study $^{30}$, in that, they found the amount of loaded 5 -FU on $\mathrm{KGM} / \mathrm{SA} / \mathrm{GO}$ nano-carrier was $32 \%$ while in our study it was $58 \%$. One possible explanation for this discrepancy is that our incubation condition $\left(24 \mathrm{~h}, 37^{\circ} \mathrm{C}\right.$, shaking $50 \mathrm{RPM}$ vs $24 \mathrm{~h}$, room temperature and without any shaking) or it may be related to the nano-carriers differences (GO vs $\mathrm{KGM} / \mathrm{SA} / \mathrm{GO}$ ). Our results regarding cell viability do not support those of Rana et al., study ${ }^{31}$ ( $26 \%$ vs $80 \%$, respectively). This difference may be due to the application of different cancer cell lines (CT26 Ds-Red vs CEM, respectively). The results of present study showed the potential of GO/5-FU as novel compound for the enhancement of anti-cancer activity of Florouracil.

\section{ACKNOWLEDGMENT}

This article prepared from from the thesis written by Mr. Behrooz Afarideh in School of Medicine Shahid Beheshti University of Medical Sciences, (Registration No: 424). The present study has been financially supported by Research Department of the School of Advanced Technologies in Medicine, Shahid Beheshti University of Medical Sciences, Tehran, Iran (grant No. 8861).

\section{REFERENCES}

1. Vos, T.; Allen, C.; Arora, M.; Barber, R.; Bhutta, Z.; Brown, A.; Carter, A.; Casey, D.; Charlson, F., and Chen., A. 2016, 388, 1545-1602

2. Feigin, V. The lancet., 2016, 388, 1459-1544.

3. Simon, N.; Vasseur, M.; Pinturaud, M.; Soichot, M.; Richeval, C.; Humbert, L.; Lebecque, M.; Sidikou, O.; Barthelemy, C., and Bonnabry, P. PloS one., 2016, 11, e0159052.

4. Thelwall, M.; Kousha, K., and Abdoli, M. Scientometrics., 2017, 112, 509-527

5. Wu, C. Surg. Oncol. Clin. N. Am., 2018, 27, 235-242.

6. Longley, D. B.; Harkin, D. P., and Johnston, P. G. Nat. Rev. Cancer., 2003, 3, 330-338.

7. Joag, M. G.; Sise, A.; Murillo, J. C.; SayedAhmed, I. O.; Wong, J. R.; Mercado, C.; Galor, A., and Karp, C. L. Ophthalmology., 2016, 123, $1442-1448$.

8. Álvarez, P.; Marchal, J. A.; Boulaiz, H.; Carrillo, E.; Vélez, C.; Rodríguez-Serrano, F.; Melguizo, C.; Prados, J.; Madeddu, R., and Aranega, A. Expert. Opin. Ther. Pat., 2012, 22, 107-123.

9. Compton, O. C. and Nguyen, S. T. Small., 2010, 6, 711-723.

10. Hummers Jr, W. S. and Offeman, R. E. J. Am. Chem. Soc., 1958, 80, 1339-1339.
11. Wei, X.; Mao, L.; Soler-Crespo, R. A.; Paci, J.T.; Huang, J.; Nguyen, S. T., and Espinosa, H. D. Nat. Commun., 2015, 6, 8026.

12. Wei, X.; Mao, L.; Soler-Crespo, R. A.; Paci, J. T.; Huang, J.; Nguyen, S. T., and Espinosa, H. D. Nat. Commun., 2017, 8, 14488.

13. Yamada, Y.; Yasuda, H.; Murota, K.; Nakamura, M.; Sodesawa, T., and Sato, S. J. Mater. Sci., 2013, 48, 8171-8198.

14. Fu, Y.-J.; Shyu, S.-S.; Su, F.-H., and Yu, P.-C. -Colloids Surf., B. 2002, 25, 269-279.

15. Chouhan, R. and Bajpai, A. J. Mater. Sci. Mater. Med., 2009, 20, 1103-1114.

16. Dutta, R. K. and Sahu, S. Eur. J. Pharm. Biopharm., 2012, 82, 58-65.

17. Ly, T. U.; Tran, N. Q.; Hoang, T. K. D.; Phan, K. N.; Truong, H. N., and Nguyen, C. K. J. Biomed. Nanotechnol., 2013, 9, 213-220.

18. Ortiz, R.; Prados, J.; Melguizo, C.; Arias, J. L.; Ruiz, M. A.; Alvarez, P. J.; Caba, O.; Luque, R.; Segura, A., and Aránega, A. Int. J. Nanomed. 2012, 7, 95.

19. Xu, Y.; Bai, H.; Lu, G.; Li, C., and Shi, G. J. Am. Chem. Soc., 2008, 130, 5856-5857.

20. Chen, L.; She, X.; Wang, T.; He, L.; Shigdar, S.; Duan, W., and Kong, L. Nanoscale., 2015, 7, 14080-14092. 
21. Berridge MV; Herst PM, and Tan AS., 2005, 11, 127-152.

22. Mosmann, T. J. Immunol. Methods., 1983, 65, 55-63.

23. Luciani, A.; Coccoli, V.; Orsi, S.; Ambrosio, L., and Netti, P. A. Biomaterials., 2008, 29, 4800-4807.

24. Hashemi, M.; Yadegari, A.; Yazdanpanah, G.; Jabbehdari, S.; Omidi, M., and Tayebi, L. RSC Advances., 2016, 6, 74072-74084.

25. Pei, y.; Feng Yang, F.; Chen, X.; Wu, N.; Wang, K, Chem. Eng., 2017, 5, 3223-3232.

26. Tran, N. Q.; Nguyen, C. K., and Nguyen, T. P. Adv. Nat. Sci.: Nanosci. Nanotech., 2013, 4, 045013.
27. El-Ghannam, A.; Ricci, K.; Malkawi, A.; Jahed, K.; Vedantham, K.; Wyan, H.; Allen, L. D., and Dréau, D. J. Mater. Sci. Mater. Med., 2010, 21, 2701-2710.

28. Ganguly, K.; Kulkarni, A. R., and Aminabhavi, T. M. Drug delivery., 2015, 1-14.

29. Liu, W.; Li, X.; Wong, Y.-S.; Zheng, W.; Zhang, Y.; Cao, W., and Chen, T. ACS nano., 2012, 6, 6578-6591.

30. Wang, J.; Liu, C.; Shuai, Y.; Cui, X., and Nie, L. Colloids Surf., B. 2014, 113, 223-229.

31. Rana, V. K.; Choi, M. C.; Kong, J. Y.; Kim, G. Y.; Kim, M. J.; Kim, S. H.; Mishra, S.; Singh, R. P., and Ha, C. S. Macromol. Mater. Eng., 2011, 296, 131-140. 